\title{
5-HYDROXYTRYPTAMINE DECREASES SOMATOSTATIN RECEPTORS AND SOMATOSTATIN-RESPONSIVE ADENYLYL CYCLASE IN RAT PANCREATIC ACINAR MEMBRANES
}

\author{
G. Muñoz-Acedo, E. Rodríguez-Martín, L. Puebla and E. Arilla*.
}

Unidad de Neuroendocrinología Molecular, Departamento de Bioquímica y Biología Molecular, Facultad de Medicina, Universidad de Alcalá, E- 28871 Alcalá de Henares, Madrid, Spain.

(Received in final form February 20, 1997)

\section{Summary}

Pretreatment of pancreatic acini with 5-hydroxytryptamine (5-HT) reduced the binding of the labeled somatostatin (SS) analogue ${ }^{125} \mathrm{I}-\mathrm{Tyr}^{3}-\mathrm{SMS}$ to pancreatic acinar membranes. This effect was dependent of the dose of 5-HT used and length of pretreatment. This inhibitory effect of 5-HT was abolished when pancreatic acini were pretreated with $5-\mathrm{HT}$ in the presence of the 5-HT $\mathrm{HT}_{1 \mathrm{P}}$ receptor-antagonist 5-hydroxytryptophyl-5-hydroxytryptophan amide (5-HTP-DP). Pretreatment of pancreatic acini with 5-HT reduced the inhibition by the stable SS analogue SMS 201-995 of basal and forskolin (FK)-stimulated adenylyl cyclase (AC) activity in pancreatic acinar membranes. There was no statistical difference established between $\mathrm{IC}_{50}$ values for the stable GTP analogue 5'-guanylylimidodiphosphate $(\mathrm{Gpp}(\mathrm{NH}) \mathrm{p})$ which inhibits ligand binding to SMS receptors in controls and in 5HT treated pancreatic cells, respectively. In addition, no significant differences were seen in the level of Gi proteins in the control and 5-HT treated panceatic acini. These data suggest that the decrease of the number of ${ }^{125} \mathrm{I}-\mathrm{THY}^{3}-\mathrm{SMS}$ receptors, would explain the decreased sensitivity of AC to SMS 201-995 in membranes from 5-HT-pretreated acini.

Key Words: somatostatin, serotonin, pancreas

Somatostatin-14 (SS), originally described by Brazeau et al. (1), is a tetradecapeptide synthesized in endocrine D cells and widely distributed in the gastrointestinal tract. At the level of the exocrine pancreas, SS is a potent inhibitor of pancreatic exocrine secretion in humans, rats and dogs (2). Several authors (3-6) have previously reported that pancreatic acini possess specific binding sites for SS which are involved in the inhibitory effect of the peptide on secretinstimulated cell cyclic adenosin 3',5'-monophosphate (cAMP). In this tissue, as in others (7), SS receptors are linked via guanine nucleotide-binding inhibitory proteins (Gi proteins) to adenylyl cyclase (AC) and SS regulates AC activity in an inhibitory manner (7). SS binding to its receptors on acinar cell membranes is not only regulated by $S S$ analogues (5) but also by several pancreatic secretagogues $(6,8)$ binding to their own receptors on pancreatic acinar cell membranes. Our group recently reported that chemical ablation of serotonergic nerves in the rat pancreas by injection of a specific 5-hydroxytryptamine (5-HT) neurotoxin, 5,7-dihydroxytryptamine $(5,7$ DHT), into the substance gland increased the number of SS receptors in pancreatic acinar cell membranes (9). These results suggest that 5-HT could decrease the activity of SS receptor-effector

*Corresponding author. Fax: 34-1-8854585 
system in the rat exocrine pancreas. However, there is no report of the influence of 5-HT on the SS receptor-effector system in the exocrine pancreas. The present study was therefore conducted to examine the effect of pretreating pancreatic acini with 5-HT on the binding of the labeled stable SS analogue SMS 204-090 or Tyr ${ }^{3}$-SMS to pancreatic acinar membranes and on the inhibition by the stable SS analogue SMS 201-995 of basal and forskolin (FK)-stimulated AC activity in these membranes. Experiments were also performed to measure the inhibition of specific ${ }^{125} \mathrm{I}-\mathrm{Tyr}^{3}-\mathrm{SMS}$ binding by the stable GTP analogue 5'guanylylimidodiphosphate (Gpp(NH)p) in order to determine the integrity of SS receptor binding site-G protein interactions.

\section{Chemicals}

\section{Materials and Methods}

The stable SS analogue, SMS 201-995 and its tyrosine analogue Tyr ${ }^{3}-S M S$ or SMS 204090 were kindly donated by Sandoz Ltd. (Basel, Switzerland). Carrier-free $\mathrm{Na}^{125}$ I (IMS 300, 100 $\mathrm{mCi} / \mathrm{ml}$ ) was purchased from the Radiochemical Center (Amersham, U.K.); collagenase (from Clostridium histoliticum) was obtained from Serva Fine Chemicals (Tebu, France). 5hydroxytryptamine (5-HT), bacitracin, phenylmethylsulphonylfluoride (PMSF), guanosine triphosphate (GTP), 5'-guanylylimidodiphosphate (Gpp(NH)p), 3-isobutyl-1-methylxanthine (IBMX) and bovine serum albumin (BSA) were supplied by Sigma Química (Madrid, Spain). 5$\mathrm{HT}_{1 \mathrm{P}}$ receptor-antagonist, 5-hydroxytryptophyl 5-hydroxytryphan amide (5-HTP-DP), was supplied by Dr Hadassah Tamir from the Depatment of Anatomy and Cell Biology, Columbia University College of Physicians and Surgeons, New York, New York 10032. All other reagents were of the highest purity commercially available.

\section{Preparation and incubation of pancreatic acini}

Male Wistar rats, weighing $225-250 \mathrm{~g}$ and fed ad libitum, were sacrificed by decapitation. The pancreas was removed and trimmed free of fat, connective tissues and lymph nodes. Acini were prepared using minor modifications of the technique developed by Amsterdam et al. (10) and Esteve et al. (11). Krebs-Ringer medium contained $24.5 \mathrm{mM}$ HEPES, $115 \mathrm{mM} \mathrm{NaCl}, 4.8$ $\mathrm{mM} \mathrm{KCl}, 1.2 \mathrm{mM} \mathrm{KH}_{2} \mathrm{PO}_{4}, 12 \mathrm{mM} \mathrm{MgSO}, 0.5 \mathrm{mM} \mathrm{CaCl}_{2}, 5 \mathrm{mM}$ glucose, $2 \mathrm{mM}$ glutamine, $0.2 \%$ (wt/vol) BSA, 2\% (vol/vol) essential amino acid solution, and $1 \%$ (vol/vol) non-essential amino acid solution. This medium was adjusted to $\mathrm{pH} 7.4$ and gassed with $\mathrm{O}_{2}+\mathrm{CO}_{2}$. The pancreas was injected with $4.16 \mathrm{ml}$ of oxygenated Krebs-Ringer medium containing 0.2 units of collagenase $/ \mathrm{ml}$. The distended pancreas was fragmented and incubated at $37^{\circ} \mathrm{C}$ and at $60-70$ oscillations/min in a shaking water bath for ten $\mathrm{min}$. After this incubation, the medium was discarded and replaced by $4.16 \mathrm{ml}$ fresh medium. The pancreas was regassed with $\mathrm{O}_{2}+\mathrm{CO}_{2}$ and the incubation repeated. The tissue was washed with Krebs-Ringer medium. Pancreatic acini were dissociated by passing the tissue through pipettes. The acinar preparation was purified by centrifugation for $1 \mathrm{~min}$ at $100 \mathrm{x}$. Pancreatic acini suspended in the afore-mentioned medium were preincubated in the presence or absence of 5-HT or other chemical agents in a shaking water bath at $37^{\circ} \mathrm{C}$ for $120 \mathrm{~min}$ unless otherwise indicated.

\section{Preparation of pancreatic acinar cell membranes and binding of ${ }^{125}$ I-Tyr ${ }^{3}-S M S$ to membranes}

Pancreatic acini after preincubation were washed once with incubation solution, transferred to $0.3 \mathrm{M}$ sucrose and homogenized at $4^{\circ} \mathrm{C}$ by use of a Potter homogenizer following the method described by Meldolesi et al. (12). After sedimentation at $1,500 \mathrm{x}$ g for $12 \mathrm{~min}$, the homogenized membranes were resuspended in $1.56 \mathrm{M}$ sucrose. This suspension was overlaid with $0.3 \mathrm{M}$ 
sucrose and centrifuged at $105,000 \times \mathrm{g}$ for $150 \mathrm{~min}$. The plasma membrane-enriched fraction collected from the interphase was diluted with distilled water and centrifuged at $15,000 \times \mathrm{g}$ for $30 \mathrm{~min}$. The supernatant was discarded and the pellet was resuspended in $50 \mathrm{mM}$ Tris/ $\mathrm{HCl}$ pH $7.4,0.01 \mathrm{mg} / \mathrm{ml}$ bacitracin, $0.2 \mathrm{mM} \mathrm{CaCl}$ and stored at $-70^{\circ} \mathrm{C}$. An aliquot was taken for protein determination by the method of Lowry et al. (13), with BSA as a standard. The stable analogue of SS, SMS 204-090, also known as Tyr ${ }^{3}$-SMS, which has been previously demonstrated to bind specifically to SS receptors with high affinity $(14,15)$, was radioiodinated by the chloramine-Tmethod (16), and purified by HPLC according to Antoniotti et al. (17). Its specific radioactivity was found to be $900 \mathrm{Ci} / \mathrm{mmol}$. Binding of ${ }^{125} \mathrm{I}-\mathrm{Tyr}^{3}-\mathrm{SMS}$ to pancreatic acinar membranes was carried out in a total volume of $250 \mu \mathrm{l}$ in $50 \mathrm{mM}$ Tris-HCl buffer (pH 7.4) containing $0.5 \mathrm{mM}$ $\mathrm{MgCl}_{2}, 3 \mathrm{mM} \mathrm{NaCl}, 0.2 \mathrm{mM} \mathrm{CaCl}, 0.2 \%$ (wt/vol) BSA, $0.5 \mathrm{mg} / \mathrm{ml}$ bacitracin and $0.3 \mathrm{mg} / \mathrm{ml}$ soybean trypsin inhibitor (binding buffer). Pancreatic acinar cell membranes (36 $\mu \mathrm{g}$ protein $/ \mathrm{ml}$ ) were incubated for $90 \mathrm{~min}$ at $20^{\circ} \mathrm{C}$ with $35 \mathrm{pM}^{125} \mathrm{I}-\mathrm{Tyr}^{3}-\mathrm{SMS}$ in the absence or presence of 0.001-10 nM unlabeled SMS 201-995. Bound and free ligand was separated by centrifugation at $11,000 \times \mathrm{g}$ for $4 \mathrm{~min}$ at $4^{\circ} \mathrm{C}$ in a microcentrifuge. Radioactivity in the pellet was measured with a gamma counter. Non-specific binding was estimated as membrane-associated radioactivity in the presence of $0.1 \mu \mathrm{M}$ SMS 201-995 and specific binding was calculated as the difference between total and non-specific membrane-associated radioactivity. The effects of Gpp(NH)p on ${ }^{125} \mathrm{I}-\mathrm{Tyr}^{3}$-SMS binding were determined after addition of a range of $\mathrm{Gpp}(\mathrm{NH}) \mathrm{p}$ concentrations (10 $11-10^{-4} \mathrm{M}$ ) in the binding assay buffer.

\section{Adenylyl cyclase assay}

AC activity was measured as previously reported (18) with minor modifications. Briefly, rat pancreatic acinar membranes $(0.12 \mathrm{mg}$ protein $/ \mathrm{ml})$ were incubated with $1.5 \mathrm{mM}$ ATP, $5 \mathrm{mM}$ $\mathrm{MgSO}_{4}, 1 \mu \mathrm{M}$ GTP and an ATP-regenerating system $(7.5 \mathrm{mg} / \mathrm{ml}$ creatine phosphate and $1 \mathrm{mg} / \mathrm{ml}$ creatine kinase), $1 \mathrm{mM}$ IBMX, $0.1 \mathrm{mM}$ PMSF, $1 \mathrm{mg} / \mathrm{ml}$ bacitracin, $1 \mathrm{mM}$ EDTA, and test substances $\left(10^{-9} \mathrm{M}\right.$ SMS $201-995$ or $\left.10^{-5} \mathrm{M} \mathrm{FK}\right)$ in $0.1 \mathrm{ml}$ of $0.025 \mathrm{M}$ triethanolamine/ $\mathrm{HCl}$ buffer (pH 7.4). After a $30 \mathrm{~min}$ incubation at $30^{\circ} \mathrm{C}$, the reaction was stopped by heating the mixture for $3 \mathrm{~min}$. After letting cool for $5 \mathrm{~min}, 0.2 \mathrm{ml}$ of an alumina slurry $(0.75 \mathrm{~g} / \mathrm{ml}$ in triethanolamine/ $\mathrm{HCl}$ buffer, $\mathrm{pH} 7.4$ ) was added and the suspension centrifuged. The supernatant was taken for assay of cAMP by the method of Gilman (19).

\section{Pertussis toxin-catalyzed ADP ribosylation}

The pertussis-toxin (PTX)-catalyzed ADP ribosylation was carried out as previously reported (20). After PTX activation, membranes $(0.8 \mathrm{mg}$ protein $/ \mathrm{ml})$ were incubated with PTX $(16 \mu \mathrm{g} / \mathrm{ml})$ in $100 \mathrm{mM}$ Tris-HCl buffer ( $\mathrm{pH} \mathrm{8.0)}$, containing $10 \mathrm{mM}$ thymidine, $1 \mathrm{mM} \mathrm{ATP}, 100$ $\mu \mathrm{M}$ GTP, $2.5 \mathrm{mM} \mathrm{MgCl}, 1 \mathrm{mM}$ EDTA, $2 \mu \mathrm{M}^{32} \mathrm{P}-\mathrm{NAD}^{+}(30 \mathrm{Ci} / \mathrm{mmol})$ and an ATPregenerating system. After $30 \mathrm{~min}$ at $30^{\circ} \mathrm{C}$, the reaction was stopped by addition of $1 \mathrm{ml}$ of icecold $100 \mathrm{mM}$ Tris- $\mathrm{HCl}$ buffer ( $\mathrm{pH} \mathrm{8.0)}$, proteins were sedimented by centrifugation for $10 \mathrm{~min}$ at $30,000 \times \mathrm{g}$ and solubilized with $0.1 \mathrm{ml} 60 \mathrm{mM}$ Tris-HCl buffer (pH 6.8) containing 10\% glycerol, $0.001 \%$ bromophenol blue and 3\% SDS (SDS-sample buffer). After heating for $30 \mathrm{~min}$ at $60^{\circ} \mathrm{C}$, the suspension was centrifuged for $10 \mathrm{~min}$ at $100,000 \times \mathrm{g}$ and aliquots of the supernatant were submitted to SDS-PAGE using the procedure of Laemmli (21) as previously described (22). The gels were run, fixed, dried and exposed to Dupont films (cronex 4) for $1-7$ days at $-80^{\circ} \mathrm{C}$ using an intensifying screen. 


\section{Data analysis}

The LIGAND computer program (23) was used to analyze the binding data. The use of this program made it possible to select the models of receptors which best fit a given set of binding data. The same program was also used to present data in the form of Scatchard plots (24) and to compute the values for receptor affinity (Kd) and density (Bmax) for each rat. Statistical comparisons of all the data were analyzed by ANOVA and the Newman-Keuls t-test. Means between groups were considered significantly different when the $p$ value was less than 0.05 . Each individual experiment was performed in duplicate.

\section{Results}

We first examined the effect of 5-HT on ${ }^{125} \mathrm{I}-\mathrm{Tyr}^{3}$-SMS binding. Freshly prepared pancreatic acini were pretreated with $10^{7} \mathrm{M} 5-\mathrm{HT}$ at $37^{\circ} \mathrm{C}$ for $120 \mathrm{~min}$ before binding of ${ }^{125} \mathrm{I}-$ Tyr ${ }^{3}$-SMS to cell membranes prepared from these pancreatic acini. Steady binding of ${ }^{125} \mathrm{I}-\mathrm{Tyr}^{3}$ SMS to both control and 5-HT-pretreated membranes was reached at 90 min (data not shown). However, pretreatment with $10^{7}$ M 5-HT markedly reduced the binding of the labeled SS analogue ${ }^{125} \mathrm{I}-\mathrm{Tyr}^{3}-\mathrm{SMS}$ to pancreatic acinar membranes in comparison with controls.

When pancreatic acini were preincubated with increasing concentrations of 5-HT $\left(10^{-11}\right.$ $10^{-5} \mathrm{M}$ ), a concentration-dependent inhibition of labeled $\mathrm{Tyr}^{3}$-SMS binding was observed (Fig. 1). The inhibitory effect of 5-HT on ${ }^{125} \mathrm{I}_{-} \mathrm{Tyr}^{3}$-SMS binding was also dependent on the length of pretreatment (Fig. 2).

${ }^{125} \mathrm{I}_{-} \mathrm{Tyr}^{3}$-SMS binding was not affected when 5-HT was added directly to the reaction mixture for the binding assay (data not shown). Therefore, the inhibitory effect was only observed when 5-HT acted on intact acinar cells and presumably affected binding through some cell processes.

In order to further understand the modulation of ${ }^{125} \mathrm{I}-\mathrm{Tyr} \mathrm{r}^{3}$-SMS binding by $5-\mathrm{HT}$, a displacement study of ${ }^{125} \mathrm{I}-$ Tyr $^{3}$-SMS binding by unlabeled SMS 201-995 was performed (Fig. 3, Left panel). The inhibitory effect of 5-HT was seen at all ligand concentrations. Scatchard analysis of labeled Tyr ${ }^{3}$-SMS binding revealed a decrease in the maximum binding capacity, with no significant effect on the binding affinity (Fig. 3, Right panel, Table 1). Such an inhibitory effect of 5-HT was abolished when pretreatment of pancreatic acini with 5-HT was performed in the presence of the 5-HT $\mathrm{H}_{1 \mathrm{p}}$ receptor-specific antagonist 5-hydroxytryptophyl-5-hydroxytryptophan amide (5-HTP-DP) (Fig. 3, Table I).

The functional coupling of SS receptors to the AC system was studied in these membrane preparations. The present results show that SMS 201-995 was able to reduce AC activity in the rat pancreatic acinar cell membranes both in basal conditions and when stimulated by FK (Table II). No significant differences were seen in either the basal or FK-stimulated AC activity between control and 5-HT-preincubated pancreatic acini. The effect of SMS 201-995 on basal and FKstimulated AC activity was markedly decreased in membranes from 5-HT-pretreated pancreatic acini (Table II). 


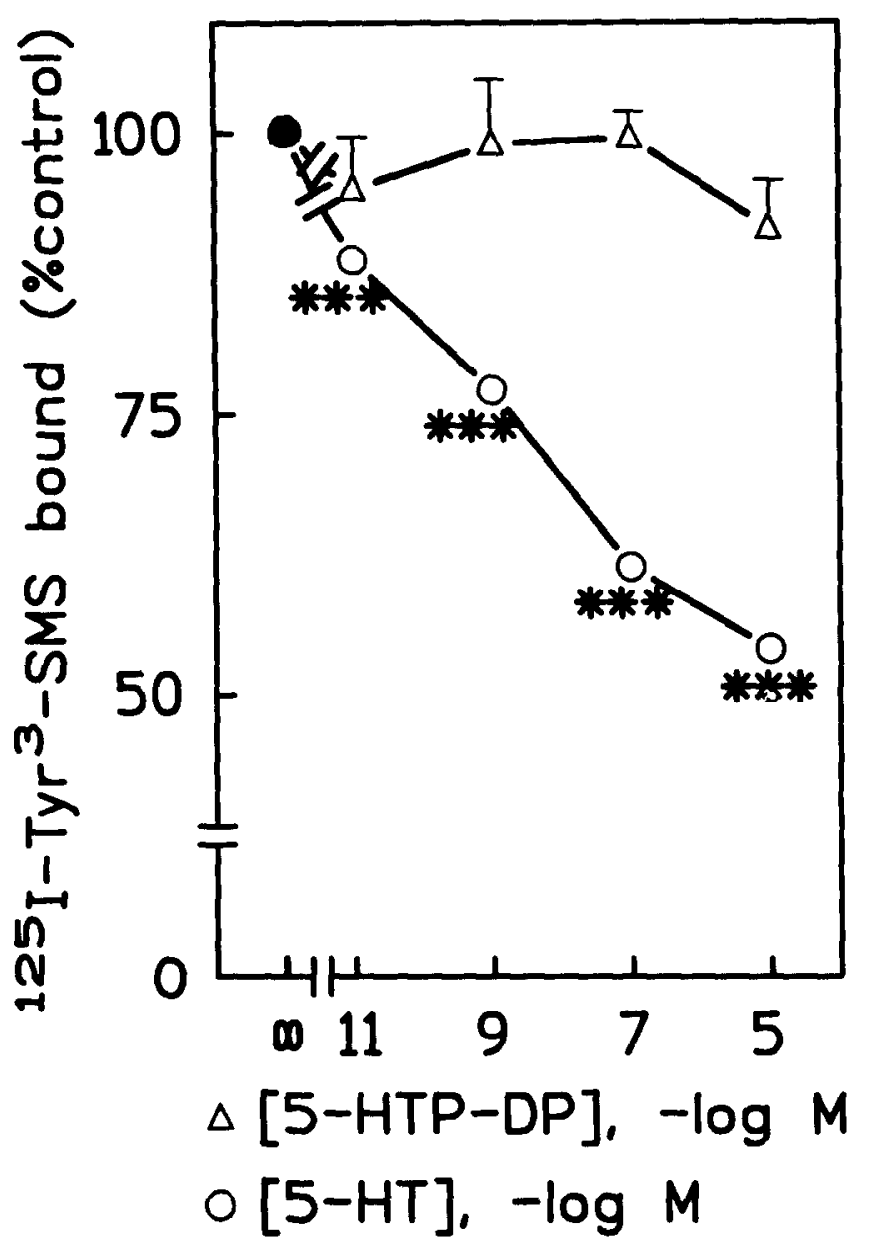

FIG. 1

Effect of pretreatment of pancreatic acini with 5-hydroxytryptamine (5-HT) or with the 5-HT $1 \mathrm{P}$ receptor-specific antagonist 5-hydroxytryptophyl-5-hydroxytryptophan amide (5-HTP-DP) on ${ }^{125} \mathrm{I}-\mathrm{Tyr}^{3}$-SMS binding to rat pancreatic acinar membranes. Pancreatic acini were preincubated for $120 \mathrm{~min}$ at $37^{\circ} \mathrm{C}$ in the absence or presence of the indicated concentrations of 5-HT $(O)$ or 5-HTP-DP $(\Delta)$ and pancreatic acinar membranes were subsequently prepared as described under "Methods". Thereafter, the prepared pancreatic acinar membranes (36 $\mu \mathrm{g}$ protein $/ \mathrm{ml})$ were incubated with $35 \mathrm{pM}^{125} \mathrm{I}-\mathrm{Tyr}^{3}$-SMS for $90 \mathrm{~min}$ at $20^{\circ} \mathrm{C}$ in the absence or presence of $10^{-7} \mathrm{M}$ of unlabeled SMS 201-995. Each value is plotted as the percent of control values ( $O$, absence of 5-HT or 5-HTP-DP) (100\%) and is the mean of duplicate determinations from five separate experiments. Statistical comparison versus control: ${ }^{* * *} p<0.001$. 


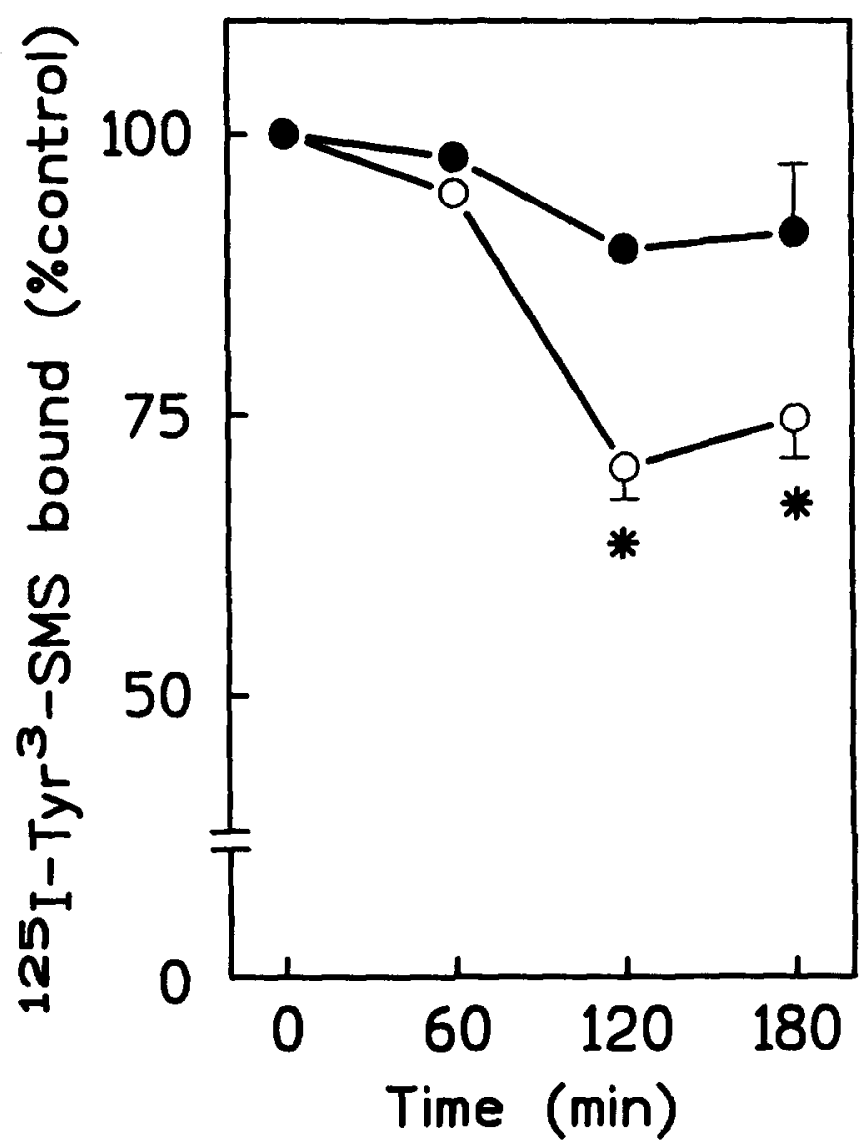

FIG. 2

Time-course study of the inhibitory effect of 5-hydroxytryptam-ine (5-HT) on ${ }^{125} \mathrm{I}$ Tyr ${ }^{3}$-SMS binding to rat pancreatic acinar membranes. Pancreatic acini were preincubated for $60-180 \mathrm{~min}$ at $37^{\circ} \mathrm{C}$ in the absence (control, $)$ ) or presence of $10^{-7} \mathrm{M}$ 5-HT (O) and pancreatic acinar membranes were subsequently prepared as described under "Methods". Thereafter, prepared pancreatic acinar membranes (36 $\mathrm{\mu g}$ protein $/ \mathrm{ml}$ ) were incubated with $35 \mathrm{pM}^{125} \mathrm{I}-\mathrm{Tyr}^{3}-\mathrm{SMS}$ for $90 \mathrm{~min}$ at $20^{\circ} \mathrm{C}$ in the absence or presence of $10^{-7} \mathrm{M}$ of unlabeled SMS 201-995. Each value is plotted as a percent of the control value and is the mean of duplicate determinations from five separate experiments. Statistical comparison versus control: ${ }^{*} \mathrm{p}<0.05$.

To determine whether changes at the level of the Gi proteins are involved in the decreased sensitivity of AC to SMS 201-995 in the pancreatic acinar membranes, the Gi proteins were evaluated. The ability of Gpp(NH)p to inhibit the binding of ${ }^{125} \mathrm{I}-\mathrm{Tyr}^{3}-\mathrm{SMS}$ was used as a functional assay for $\mathrm{Gi}$ proteins. The modulation of ${ }^{125} \mathrm{I}-\mathrm{Tyr}^{3}$-SMS binding by guanine nucleotides was studied in fresh and 5-HT-preincubated pancreatic acini. There was no statistical difference established between $\mathrm{IC}_{50}$ values for $\mathrm{Gpp}(\mathrm{NH}) \mathrm{p}$ which inhibits ligand binding to SMS receptors in control and in 5-HT treated cells, respectively (Fig. 4). 


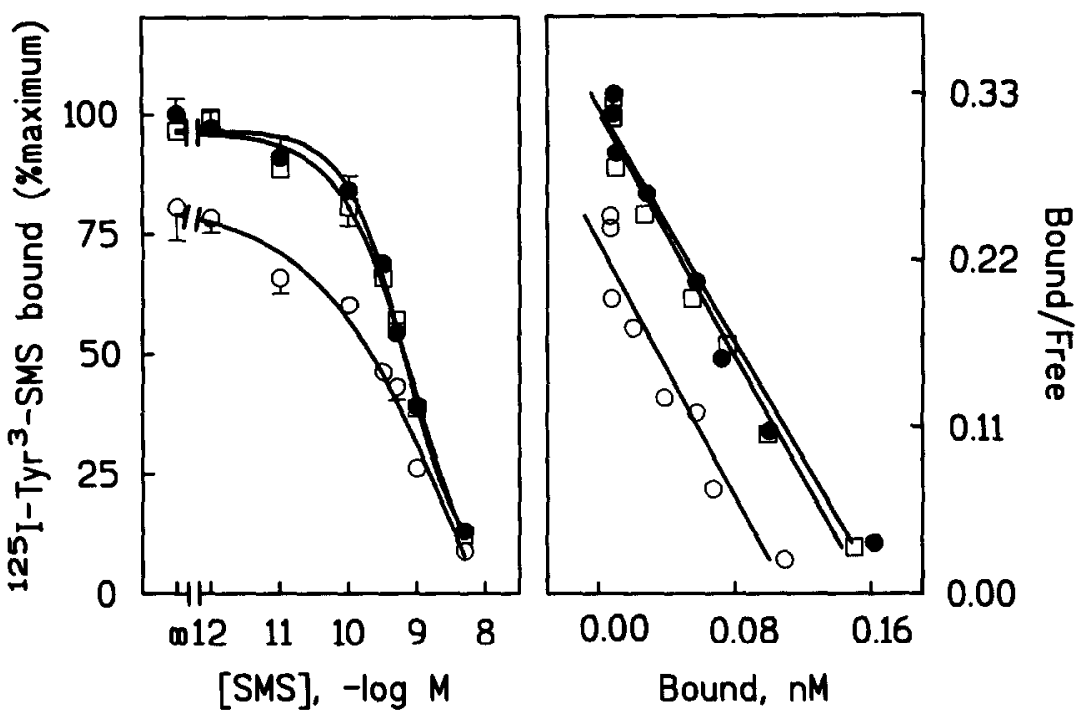

FIG. 3

Competitive inhibition curve and scatchard analysis of ${ }^{125}-{ }^{-}-\mathrm{Tyr}^{3}$-SMS binding to pancreatic acinar membranes. Left panel: After preincubation of pancreatic acini for $120 \mathrm{~min}$ at $37^{\circ} \mathrm{C}$ in the absence (control, O) or presence of $10^{-7} \mathrm{M} \mathrm{5-}$ hydroxytryptamine (5-HT) (O), or $10^{-7}$ M 5-HT plus $10^{-7}$ M 5-hydroxytyptophyl-5hydroxytryptophan amide (5-HTP-DP) ( $\square$ ), pancreatic acinar membranes were prepared as described under "Methods". Thereafter, the prepared acinar membranes (36 $\mu \mathrm{g}$ protein $/ \mathrm{ml}$ ) were incubated with $35 \mathrm{pM}^{125} \mathrm{I}$-Tyr $\mathrm{T}^{3}$-SMS for 90 $\mathrm{min}$ at $20^{\circ} \mathrm{C}$ in the presence of increasing concentrations of unlabeled SMS 201-995 (SMS). Specific saturable binding was expressed as a percent of the maximum specific binding. Each value is the mean of duplicate determinations from five separate experiments. Right panel: Scatchard plots of the same data.

\section{TABLE I}

Effect of pretreatment of pancreatic acini with 5-hydroxytryptamine (5-HT) and 5-HT plus 5hydroxytryptophyl-5-hydroxytryptophan amide (5-HTP-DP) on equilibrium parameters for ${ }^{125} \mathrm{I}-$ $\mathrm{Tyr}^{3}$-SMS binding in rat pancreatic acinar membranes.

\begin{tabular}{lll}
\hline Groups & \multicolumn{1}{c}{ Bmax } & Kd \\
\hline Controls & $4605 \pm 30$ & $0.50 \pm 0.03$ \\
5-HT & $3073 \pm 80^{* * *}$ & $0.47 \pm 0.01$ \\
Controls & $4656 \pm 260$ & $0.53 \pm 0.01$ \\
5-HTP-DP plus 5-HT & $4395 \pm 40$ & $0.49 \pm 0.01$
\end{tabular}

Pancreatic acini were preincubated for $120 \mathrm{~min}$ at $37^{\circ} \mathrm{C}$ with $10^{-7} \mathrm{M}$ 5-HT in the presence or absence of $10^{-7} \mathrm{M}$ 5-HTP-DP. Specific labeled Tyr ${ }^{3}$-SMS binding to these pancreatic acinar membranes was then determined. Binding parameters were calculated by Scatchard plots on linear regression. Units for $\mathrm{Kd}$ are $\mathrm{nM}$ and units for Bmax are femtomol of ${ }^{125} \mathrm{I}-\mathrm{Tyr}{ }^{3}$-SMS bound per $\mathrm{mg}$ of protein. The results are represented as the means \pm S.E.M. of five separate experiments. Statistical comparison versus controls: $* * * p<0.001$. 
TABLE II

Effect of the somatostatin analogue SMS 201-995 $\left(10^{-9} \mathrm{M}\right)$ and forskolin $(\mathrm{FK})\left(10^{5} \mathrm{M}\right)$ on adenylyl cyclase (AC) activity (pmol cAMP/min/mg protein) in pancreatic acinar membranes.

\begin{tabular}{lcc}
\hline & Control & 5 -HT \\
\hline Basal activity & $11.20 \pm 0.88$ & $11.53 \pm 0.72$ \\
$+10^{-9}$ M SMS 201-995 & $8.73 \pm 0.49$ & $10.12 \pm 0.31 *$ \\
$P$ & $<0.05$ & N.S. \\
$+10^{-5}$ M FK & $39.01 \pm 1.74$ & $41.01 \pm 0.28$ \\
$P$ & $<0.001$ & $<0.001$ \\
Fold increases in FK stimulation & $3.48 \pm 0.26$ & $3.55 \pm 0.22$ \\
over basal & $26.34 \pm 0.33$ & $35.50 \pm 0.94 * * *$ \\
$10^{-5}$ M FK + 10-9 M SMS 201-995 & $<0.001$ & $<0.001$ \\
$P$ & & \\
\%SMS 201-995 inhibition & $32.47 \pm 1.68$ & $13.43 \pm 1.89 * * *$ \\
of FK stimulation & &
\end{tabular}

After incubation of pancreatic acini for $120 \mathrm{~min}$ at $37^{\circ} \mathrm{C}$ in the absence (control) or presence of $10^{-7} \mathrm{M}$ of 5-hydroxytryptamine (5-HT), pancreatic acinar membranes were prepared as described under "Methods". Experiments were performed as described in Methods. Values represent the means \pm S.E.M. of the determinations performed. Statistical comparisons between stimulated and inhibited basal activities induced by $10^{-5} \mathrm{M}$ FK and $10^{-9} \mathrm{M}$ SMS 201-995 respectively, and their corresponding basal activities are shown as $P$ values. Similary, those between inhibition by $10^{9}$ M SMS 201-995 of the FK stimulated activities and their corresponding FK stimulated activities are represented by $\underline{\mathrm{P}}$ values. Statistical comparisons between 5-HT and control group are shown by asterics: ${ }^{*} \mathrm{p}<0.05,{ }^{* * *} \mathrm{p}<0.001$.

Further experiments explored the effect of 5-HT administration on Gi proteins in rat pancreatic acinar membranes by ADP-rybosylation of the $\alpha$-subunit of Gi with PTX in the presence of ${ }^{32} \mathrm{P}-\mathrm{NAD}^{+}$. Fig. 5 shows that the radioactivity was incorporated into the $41-\mathrm{kDa}$ membrane protein upon the addition of PTX and that the intensity of the labeling was the same in membranes from control and 5-HT treated pancreatic acini.

\section{Discussion}

The present results show that preincubating rat pancreatic acini with 5-HT reduces the subsequent binding of ${ }^{125} \mathrm{I}-\mathrm{Tyr}^{3}$-SMS to pancreatic acinar cell membranes. This action of 5-HT depends on the incubation time and concentration of 5-HT.

The rapid degradation of SS has led to the search for more stable analogues, which were synthesized mainly as octa- and nonapeptides (25). One of them is SMS 201-995, a long-acting SS analogue (25), bound specifically and with high affinity to SS receptors in various systems (26). Its $\mathrm{Tyr}^{3}$ analogue, code named 204-090, shares with SMS 201-995 the above-mentioned properties, i.e. it displaces with high affinity a ${ }^{125} \mathrm{I}-\mathrm{Tyr}^{11}$-SS radioligand from all its binding sites in pituitary or pancreatic homogenates. It may act in a same way on the binding sites in cortical or hippocampal membranes (14). 


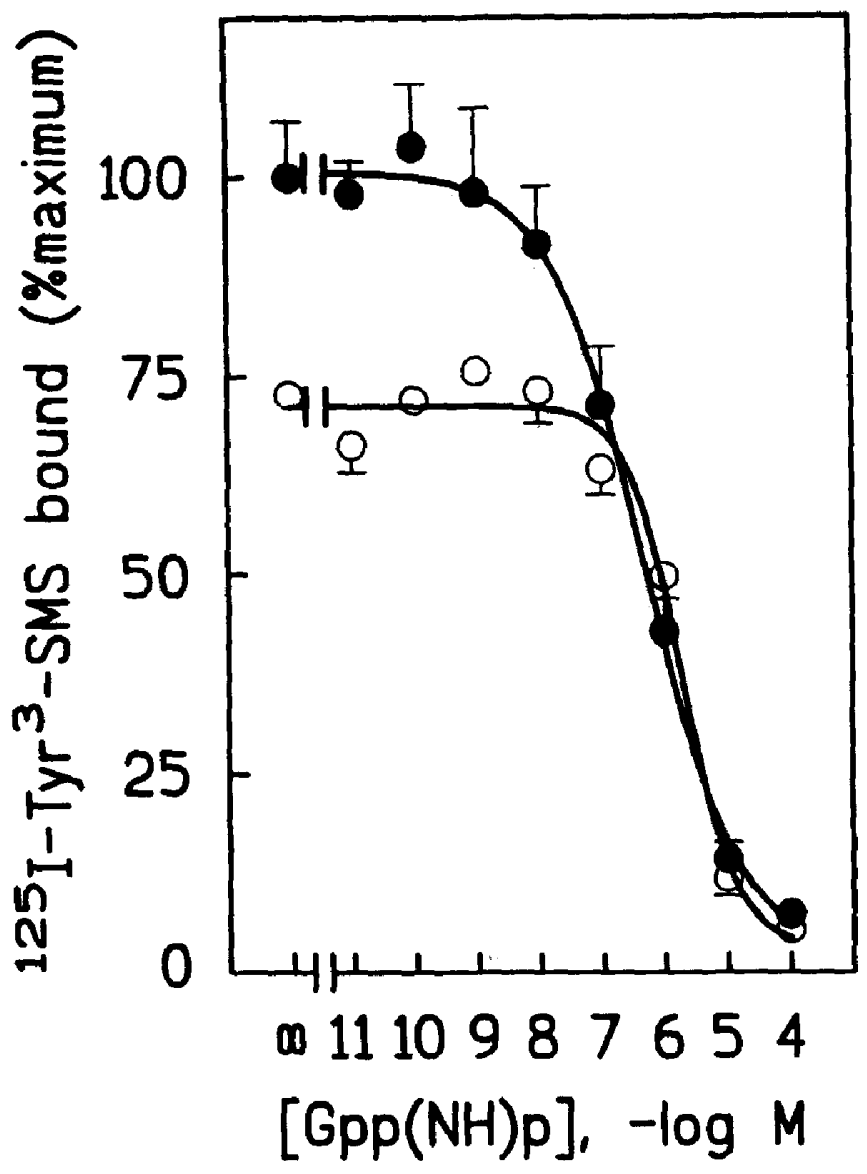

FIG. 4.

Effect of pretreatment of pancreatic acini with 5-hydroxytryptamine (5-HT) on the inhibitory effect of 5'-guanylylimidodiphosphate $(\mathrm{Gpp}(\mathrm{NH}) \mathrm{p})$ on the specific binding of ${ }^{125} \mathrm{I}-\mathrm{Tyr}^{3}$-SMS. After preincubation of pancreatic acini for $120 \mathrm{~min}$ at $37^{\circ} \mathrm{C}$ in the absence (control, $O$ ) or presence of $10^{-7} \mathrm{M} 5-\mathrm{HT}(\mathrm{O})$, pancreatic acinar membranes were prepared as described under "Methods". Thereafter, prepared pancreatic acinar membranes $(36 \mu \mathrm{g}$ protein $/ \mathrm{ml}$ ) were incubated with 35 pM ${ }^{125}$ I-Tyr ${ }^{3}$-SMS for 90 min at $20^{\circ} \mathrm{C}$ in the absence or presence of increasing concentrations of $\mathrm{Gpp}(\mathrm{NH}) \mathrm{p}$. Specific binding observed in the presence of increasing concentrations of $\mathrm{Gpp}(\mathrm{NH}) \mathrm{p}$ is depicted as percent of maximal binding observed in the absence of the nucleotide. Each point is the mean of duplicate determinations from five separate experiments. Calculated $50 \%$ inhibitory concentration values were $0.40 \mu \mathrm{M}$ in membranes from control pancreatic acini and 2.37 $\mu \mathrm{M}$ in those from pancreatic acini preincubated with 5-HT. No statistical significant differences were found between $\mathrm{IC}_{50}$ values.

The binding parameters of the SS receptors in control membranes were similar to those previously reported $(5,27)$. Although recent gene cloning studies have demonstrated the existence of different SS receptor isoforms (28), the pancreas seems to express only the SS receptor subtype 2 (SSTR2) (29). 
The effect of 5-HT on the pancreatic somatostatinergic system seems to be mediated by the specific 5-HT ${ }_{1 P}$ receptor. The decrease in ${ }^{125} \mathrm{I}-\mathrm{Ty} \mathrm{r}^{3}-\mathrm{SMS}$ binding can be abolished by addition of 5-HTP-DP, a 5-HT 1 receptor-specific antagonist (30), to the incubation media. This action of 5-HTP-DP coupled with the finding that 5-HT does not alter the binding of ${ }^{125} \mathrm{I}-\mathrm{Tyr}^{3}$-SMS when added directly to the binding media indicates that the ability of 5-HT to inhibit the binding of ${ }^{125} \mathrm{I}-$ Tyr $^{3}$-SMS is mediated by 5-HT interacting with $5-\mathrm{HT}_{1 \mathrm{P}}$ receptors and does not reflect a direct interaction of 5-HT with SS receptors.

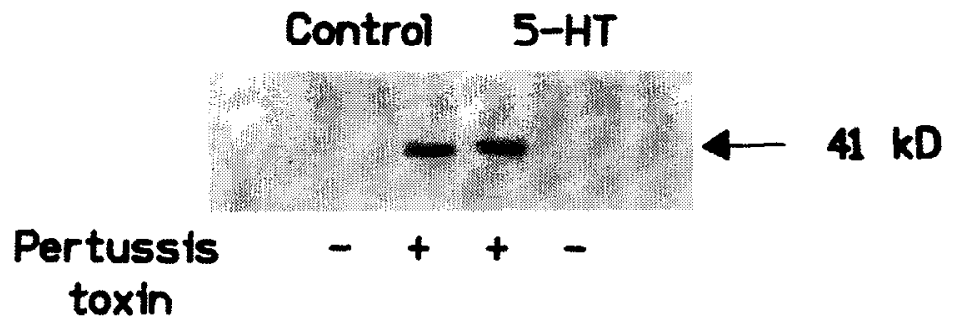

FIG. 5.

Autoradiographs of ${ }^{32} \mathrm{P}$-ADP-ribosylated pancreatic acinar membranes proteins. Pancreatic acinar membranes $(0.8 \mathrm{mg}$ protein $/ \mathrm{ml})$ from controls and 5 hydroxytrptamine (5-HT) treated pancreatic acinis, were incubated for $30 \mathrm{~min}$ at $30^{\circ} \mathrm{C}$ in the presence of $2 \mu \mathrm{M}^{32} \mathrm{P}-\mathrm{NAD}^{+}(30 \mathrm{Ci} / \mathrm{mmol})$, with $(+)$ or without $(-)$ pertussis toxin (PTX) $(16 \mu \mathrm{g} / \mathrm{ml})$. These experiments are representative of three others. For details, see Materials and Methods section.

The mechanism by which 5-HT decreases the SS receptors in pancreatic acini remains to be elucidated. Occupation of the $5-\mathrm{HT}_{1 \mathrm{P}}$ receptors by an agonist increases cell cAMP, a wellknown second messenger (31). These findings, together with the present results, suggest that increased cytosolic cAMP induced by 5-HT might affect the binding of labeled Tyr ${ }^{3}$-SMS, presumably through activation of a CAMP-dependent protein kinase (PKA). In this regard, it has been shown that the pretreatment of pancreatic acini with exogenously added cAMP derivates causes an inhibitory effect on labeled SS binding to membranes (6). In addition, the exposure of acini to either VIP or secretin, which would increase cell cAMP, significantly reduces subsequent labeled SS binding to the acinar membranes (6).

Inhibition of rat AC activity by SMS 201-995 was found, which is in agreement with the literature $(32,33)$. The attenuation of the inhibitory effect of SMS 201-995 on basal and FKstimulated AC activity in pancreatic acini preincubated with 5-HT is most likely due, at least in part, to the observed decrease of ${ }^{125}{ }^{-T y}{ }^{3}-S M S$ receptors.

The present results concerning the ablity of the non hydrolyzable GTP analogue Gpp(NH)p to inhibit the binding of the tracer to pancreatic acinar membranes and the studies of PTX catalized ADP-ryboylation suggest, that Gi proteins were not modified in 5-HT treated pancreatic acini when compared with controls.

The data obtained allow us to exclude the possibility that 5-HT affected the functioning of the AC catalytic subunit. In this context, the effect of pretreatment of pancreatic acini with 
5-HT on basal cAMP levels did not differ between control and 5-HT-exposed pancreatic acini. The catalytic subunit of AC can be directly stimulated by the diterpene FK (34), and cAMP production induced by FK can therefore be considered as an estimate of the enzymatic activity of AC. The present results also show that FK-stimulated AC activity was not affected by 5-HT. Therefore, the present study suggest that the decrease of the number of ${ }^{125} \mathrm{I}-\mathrm{Tyr}^{3}$-SMS receptors would explain the diminished sensitivity of AC to SMS 201-995 in membranes from 5-HTpretreated pancreatic acini.

The physiological meaning of the 5-HT-induced down-regulation of the functional SS receptor-effector system is not known. Serotonergic innervation in the pancreas may be derived exclusively from the myenteric plexus of the stomach and duodenum (35). Although most serotonergic immunoreactive axons in the pancreas terminate in ganglia, some fibers are also observed near the pancreatic acini (35). Therefore, it is possible that released 5-HT binds to 5$\mathrm{HT}_{1 \mathrm{P}}$ receptors present in pancreatic acinar cell membranes $(30,36)$. The inhibition of the SS receptor-effector system could represent a part of the homeostatic response to 5-HT. This downregulation manifests itself physiologically by decreasing acinar cell sensitivity to SS action.

\section{Acknowledgements}

This study was supported by Grants from the University of Alcalá (0.01/96) and DGICYT (PM95-0041). The authors thank Carol F. Warren and Jerry Keller from the Alcala University Institute of Education Sciences for their linguistic assistance and Angela Martin for her technical assistance. The peptides SMS 201-995 and Tyr ${ }^{3}$-SMS were generously supplied by Sandoz Ltd., (Basel, Switzerland).

\section{References}

1. P. BRAZEAU, W. VALE, R. BURGUS, N. LING, M. BUTCHER, J. RIVIER and R. GUILLEMIN, Science 129 77-79 (1973).

2. T. HEINTGES, R. LÜTHEN and C. NIEDERAU, Digestion 55 1-9 (1994).

3. J.P. ESTÈVE, C. SUSINI, N. VAYSSE, H. ANTONIOTTI, E. WUNSCH, G. BERTHON and A. RIBET, Am. J. Physiol. 247 G62-G69 (1984).

4. C. SAKAMOTO, I.D. GOLDFINE and J.A. WILLIAMS, J. Biol. Chem. 259 9623-9627 (1984).

5. C.B. SRIKANT and Y.C. PATEL, J. Biol. Chem. $2617690-7696$ (1986).

6. T. MATOZAKI, C. SAKAMOTO, M. NAGAO and S. BABA, Horm. Metabol. Res. 20 141-144 (1988).

7. C. SAKAMOTO, T. MATOZAKI, M. NAGAO and S. BABA, Am. J. Physiol. 253 G308-G314 (1987).

8. C. SAKAMOTO, T. MATOZAKI, M. NAGAO, H. NISHISAKI and S. BABA, Pancreas 3 18-24 (1988).

9. G. MUÑOZ-ACEDO, I. ALVARO-ALONSO and E. ARILLA, J. Endocrinol. 145 227234 (1995).

10. A. AMSTERDAM, T.E. SALOMON and J.D. JAMIESON, Methods Cell Biol. 20 361378 (1978).

11. J.P. ESTËVE, N. VAYSSE, C. SUSINI, J.M. KUNSCH, D. FOURMY, L. PRADAYROL, E. WUNSCH, L. MORODER and A. RIBET, Am. J. Physiol. 245 G208-G216 (1983).

12. J. MELDOLESI, J.D. JAMIESON and G.E. PALADE, J. Cell Biol. 49 109-129 (1971). 
13. O.H. LOWRY, N.J ROSEBROUGH, A.L FARR and R.J. RANDALL, J. Biol. Chem. 193 265-275 (1951).

14. J.C. REUBI, Life Sci. 36 1829-1836 (1985).

15. S. KNUHTSEN, J.P ESTEVE, B. BERNADET, N. VAYSSE and C. SUSINI, Biochem. J. 254 641-647 (1988).

16. F.C. GREENWOOD, W.M. HUNTER and J.S. GLOVER, Biochem. J. 89 114-123 (1963).

17. H. ANTONIOTTI, P. FAGOT-REVURAT, J.P. ESTEVE, D. FOURMY, L. PRADAYROL and A. RIBET, J. Chromatog. 296 181-188 (1984).

18. M.D. HOUSLAY, J.C. METCALFE, G.P. WARREN, T.R. HESKETH and G.A. SMITH, Biochim. Biophys. Acta 436 489-494 (1976).

19. A.G. GILMAN, Proc. Nat. Acad. Sci. USA. 67 305-312 (1970).

20. G.M. BOKOCH, T. KATADA, J.K. NORTHUP, E.L. HEWLETT and A.G. GILMAN. J. Biol. Chem. 258 2072-2075 (1983).

21. U.K. LAEMMLI. Nature 227 680-685 (1970).

22. M. LABURTHE, B. BREANT and C. ROUYER-FESSARD. Eur. J. Biochem. 139 181187 (1984).

23. P.J. MUNSON and D. RODBARD, Anal. Biochem. 1207 220-239 (1980).

24. G. SCATCHARD, Ann. N.Y. Acad. Sci. 51 669-671 (1949).

25. W. BAUER, U. BRINER, W. DOEPFNER, R. HALLER, R. HUGUENIN, P. MARBACH, T.J. PETCHER and J. PLESS. Life Sci. 31 1133-1140 (1982).

26. J.C. REUBI. Neurosci. Lett. 49 259-263 (1984).

27. N. VIGUERIE, N. TAHIRI-JOUTI, J.P. ESTÈVE, P. CLERC, C. LOGSDON, M. SVOSOBA, C. SUSINI, N. VAYSSE and A. RIBET, Am. J. Physiol. 255 6113-6120 (1988).

28. G.I. BELL and T. REISINE, Trends Neurosci. 16 34-38 (1993).

29. J. BRUNO, Y. XU, J. SONG and M. BERELOWITZ, Endocrinology 133 2561-2567 (1993).

30. A.L. KIRCHGESSNER, M.-T. LIU, H. TAMIR and M.D. GERSHON, Am. J. Physiol. 262 G553-G566 (1992).

31. Y. XIA, R.H. FERTEL and J.D. WOOD, Life Sci. 55 685-692 (1994).

32. N. VIGUERIE, N. TAHIRI-JOUTI, J.P. ESTEVVE, P. CLERC, C. LOGSDON, M. SVOBODA, C. SUSINI, N. VAYSSE and A. RIBET, Am. J. Physiol. 255 G113-G120 (1988).

33. K. MATSUSHITA, Y. OKABAYASHI, H. HASEGAWA, M. KOIDE, Y. KIDO, T. OKUTANI, Y. SUGIMOTO and M. KASUGA, Gastroenterology 104 1146-1152 (1993).

34. K.B. SEAMON and J.W. DALY, In: Advances in Cyclic Nucleotide and Protein Phosphorylation Research, Raven Press, New York, Vol. 17 p. 1-150 (1986).

35. A.L. KIRCHGESSNER and M.D. GERSHON, J. Neurosci. 10 1626-1642 (1990).

36. A.L. KIRCHGESSNER, M.T. LIU, M.J. HOWARD and M.D. GERSHON, J. Comp. Neurol. 327 233-250 (1993). 